\title{
Short Communication \\ Record of Conotelus luteicornis Erichson (Coleoptera: Nitidulidae) in passion fruit vine in Acre state, Brazil
}

\author{
Rodrigo Souza Santos $^{1 *}$ (D), Josef Jelínek ${ }^{2}$, Romeu de Andrade Carvalho Neto ${ }^{1}$ \\ 10.1590/0034-737X202168040015
}

\begin{abstract}
The first record of Conotelus luteicornis Erichson (Coleoptera: Nitidulidae) was made in a commercial passion fruit vine planting in the municipality of Senador Guiomard, Acre state, Brazil. The insects were found inside the flowers where larvae and adults feed, causing early abortion and, consequently, losses in production. Therefore, the first record of this species is made in the Brazilian Amazon. Researches related to damage level, population dynamics, prospecting for natural enemies, and control methods are strongly recommended since this nitidulid is an insect with high harmful potential to the passion fruit vine culture in the Amazon region.
\end{abstract}

Keywords: Amazon; Cucujoidea; Cillaeinae; Malpighiales; Passifloraceae

\section{INTRODUCTION}

Originating in the tropical region of South America, passion fruit (Passiflora spp.; Passifloraceae) is widely cultivated and commercialized in Brazil, with around 150 native species registered in the country (Cervi et al., 2010). In Amazon, the most cultivated species is the yellow or sour passion fruit, Passiflora edulis Sims (Passifloraceae), and its fruits are used mainly for the production of juice, sweets, jellies, ice creams and other culinary products (Morais et al., 2016). The intense yellow or orange color of its pulp is due to carotenoid pigments, which act as antioxidants in the prevention of diseases and aging processes (Carvalho et al., 2015). Acre state, Brazil has an area of 138 ha cultivated with passion fruit, production of 1,068 tons and average yield of $8.5 \mathrm{tha}^{-1}$. The largest planted areas are found in the municipalities of Senador Guiomard, Rio Branco and Plácido de Castro, which together account for $67 \%$ of the State's planted area (IBGE, 2020).

The social aspect of passion fruit culture has great relevance since it is a vine fruit cultivated predominantly by family producers in small areas (from 1 to 4 ha) and promotes job creation and workforce stability in the rural environment (Souza et al., 2002). However, in Brazil, the cultivation of this fruit tree is surrounded by phytosanitary problems, causing economic losses for producers.

Passion fruit growing is associated with a numerous complex of insects and mites, which can cause severe economic damage and compromise this agricultural activity, depending on its population levels. Defoliating caterpillars and sucking bugs are the main pests of passion vine in Brazil (Fadini \& Santa-Cecília, 2000; Picanço et al., 2001; Aguiar-Menezes et al., 2002; Lunz et al., 2006).

This work aimed to determine the pest species responsible for the abortion of flowers in a commercial passion fruit planting in Acre state, Brazil.

\section{MATERIAL AND METHODS}

In August 2019, a technical visit was carried out to a commercial passion fruit plantation of cultivar BRS Yellow Giant, with high flower abortion rate, located in the municipality of Senador Guiomard, Acre state, Brazil (09 58'39.9"S; 6758'38.0"W). The area was grown in 2018 and the plants received the cultural treatments

\footnotetext{
Submitted on September 22 $2^{\text {nd }}, 2020$ and accepted on May 27th 2021.

${ }^{1}$ Embrapa Acre, Rio Branco, Acre, Brazil. rodrigo.s.santos@embrapa.br; romeu.andrade@embrapa.br

${ }^{2}$ National Museum, Horní Poèernice, Czech Republic. jj.nitidula@seznam.cz

*Corresponding author: rodrigo.s.santos@embrapa.br
} 
recommended for the crop, with the application of phytosanitary products every 15 days.

In the morning, 10 flowers were collected during a random walk-through at the plantation. The flowers were opened and it was verified the presence of small coleopterans inside them. The insects were collected, placed in a glass bottle containing $70 \%$ alcohol, and sent to a Nitidulidae's specialist, one of this work's co-authors, for identification at the lowest possible taxonomic level. The identification was performed by comparing the external morphology of the specimens collected in the state of Acre, with the holotype deposited in Museum of Natural History of the Humboldt University, Berlin, Germany.

\section{RESULTS AND DISCUSSION}

The beetles were identified as Conotelus luteicornis Erichson (Coleoptera: Nitidulidae) (Figure 1) based on the comparison with the holotype specimens. The adult measures approximately $4.0 \mathrm{~mm}$ in length with an elongated dark-colored body (Potin et al., 2016). Antennae 11segmented and club with three antennomeres inserted between the eyes and the mandible base. Pentamerous tarsus, with the fourth joint shortened. Reduced elytra, brachelytry type, exposing the last five abdominal sclerites. It presents the prothorax quite detached of the body, bigger than the mesothorax and the metathorax, which are covered by the wings (Habeck, 2002).

The genus Conotelus includes 25 beetle species native to the American continent (Williams et al., 1988). Nitidulid species commonly feed on decaying fruits and fermented juices from plants and fungi, but some live on flowers (Arnett Junior et al., 2002). Conotelus species have already been recorded in flowers of Monotagma plurispicatum (Koern.) K. Shum. (Marantaceae) and passion fruit (Passiflora sp.; Passifloraceae) in the Amazon (Albuquerque, 1974; Potin et al., 2016), Calystegia sepium (L.) in the United States (Price \& Young, 2006), passion fruit in Hawaii (Nishida, 1957), cedar fruits (Cedrela odorata L .; Meliaceae) in Argentina (Velasquez, 1984), Hibiscus spp. (Malvaceae) in Australia (Lachance et al., 2001), tomatoes and cloves in Minas Gerais State, Brazil (Haro, 2011).

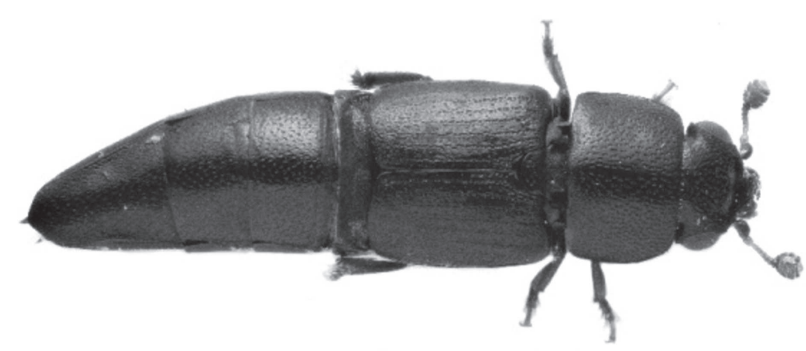

Figure 1: Conotelus luteicornis Erichson (Coleoptera: Nitidulidae) (B\& adulto) in dorsal habitus. (Picture: Jiøí Hájek).
Conotelus sp. associated with passion fruit flowers in Rondônia state, Brazil was reported by Potin et al. (2016). Azevedo et al. (2005) registered another nitidulid species, Brachypeplus sp. (Coleoptera: Nitidulidae) infesting passion fruit flowers in Ceará state, Brazil. This reinforces the fact that passion fruit vine is a preferred host plant for feeding some beetles species in this family.

According to producers' reports in Rondônia state, the economic loss resulting from the attack of these coleopterans in commercial passion fruit plantations can reach up to $80 \%$. Young flowers and fruits can be aborted in high infestations of these nitidulids in the culture and the fruits that do not fall are blackened and deformed. Besides, injuries caused by these insects fed on passion flowers can serve as a gateway for opportunistic pathogens (Potin et al., 2016).

\section{CONCLUSION}

This work records $C$. luteicornis associated with passion fruit cultivation in the Brazilian Amazon for the first time. Researches on damage level, population dynamics, prospecting for natural enemies, and control methods are strongly recommended since this nitidulid is an insect with high harmful potential to the passion fruit culture in the Amazon region.

\section{ACKNOWLEDGMENTS}

The authors would like to thank Mr. Germano for assigning the study area. Authors inform that there is no conflict of interest in carrying the research and publishing this manuscript.

\section{REFERENCES}

Aguiar-Menezes EL, Menezes EB, Cassino PCR \& Soares MA (2002) Passion fruit. In: Peña JL, Sharp JL \& Wysoki M (Eds.) Tropical fruit pests and pollinators: economic importance, natural enemies and control. New York, CAB International. p.361-390.

Albuquerque LP (1974) Observações sobre ataque de insetos em folhas de Marantaceae. Acta Amazonica, 4:57-61.

Arnett Junior RH, Thomas MC, Skelley PE \& Frank JH (2002) American beetles, volume II: Polyphaga: Scarabaeoidea through Curculionoidea. London, CRC Press. 861p.

Azevedo FR, Guimarães JA, Mesquita ALM \& Braga Sobrinho R (2005) Ocorrência e danos do besouro-da-flor-do-maracujazeiro-amarelo. Fortaleza, Embrapa Agroindústria Tropical. 3p. (Comunicado Técnico, 105).

Carvalho SLC, Stenzel NMC \& Auler PAM (2015) Maracujáamarelo: recomendações técnicas para o cultivo no Paraná. Londrina, IAPAR. 54p. (Boletim Técnico, 83).

Cervi AC, Milward-de-Azevedo MA \& Bernacci LC (2010) Passifloraceae. In: Lista de espécies da flora do Brasil. Available at: <http://floradobrasil.jbrj.gov.br/2010/FB000182>. Accessed on: June $24^{\text {th }}, 2020$.

Fadini MAM \& Santa-Cecília LVC (2000) Manejo integrado de pragas do maracujazeiro. Informe Agropecuário, 21:29-33. 
Habeck DH (2002) Nitidulidae Latreille 1802. In: Arnett Junior RH, Thomas MC, Skelley PE \& Frank JH (Eds.) American beetles - Polyphaga: Scarabaeoidea through Curculionoidea. London, CRC Press. p.311-315.

Haro MM (2011) Controle biológico conservativo de pragas em cultivo protegido de tomate orgânico. Dissertação de Mestrado. Universidade Federal de Lavras, Lavras. 88p.

IBGE - Instituto Brasileiro de Geografia e Estatística (2020) Estatísticas sobre a produção agrícola municipal. Available at $\langle$ https://sidra.ibge.gov.br/tabela/5457\#resultado>. Accessed on: June $24^{\text {th }}, 2020$.

Lachance MA, Starmer WT, Rosa CA, Bowles JM, Barker JSF \& Jansen DH (2001) Biogeography of the yeasts of ephemeral flowers and their insects. FEMS Yeast Research, 1:1-8.

Lunz AM, Souza LA \& Lemos W P (2006) Reconhecimento dos principais insetos-praga do maracujazeiro. Pará, Embrapa Amazônia Oriental. 36p. (Documento, 245).

Morais EGF, Lemos WP, Acioli ANS, Oliveira JS, Adaime R \& Marsaro Júnior AL (2016) Maracujá. In: Silva NM, Adaime R \& Zucchi RA (Eds.) Pragas agrícolas e florestais na Amazônia. Brasília, Embrapa. p.201-221.

Nishida T (1957) Food plants, distribution and variation in abundance of Conotelus mexicanus Murray, a recently discovered immigrant insect in Hawaii (Coleoptera: Nitidulidae). Proceedings of Hawaiian Entomological Society, 16:307-312.
Picanço M, Gonring AHR \& Oliveira IR (2001) Manejo integrado das pragas. In: Bruckner $\mathrm{CH} \&$ Picanço MC (Eds.) Maracujá: tecnologia de produção, pós-colheita, agroindústria, mercado. Porto Alegre, Cinco Continentes. p.189-242.

Potin DM, Andrade GS, Pereira RZ \& Kassab SO (2016) Conotelus sp. (Coleoptera: Nitidulidae), a new insect pest of passion fruit in the Amazon Biome. Florida Entomologist, 99:580-582.

Price MB \& Young DK (2006) An annotated checklist of Wisconsin sap and short-winged flower beetles (Coleoptera: Nitidulidae, Kateretidae). Insecta Mundi, 20:79-84.

Souza JS, Cardoso CEL, Lima AA \& Coelho EF (2002) Aspectos socioeconômicos. In: Lima AA (Ed.) Maracujá produção: aspectos técnicos. Brasília, Embrapa Informação Tecnológica. p.10.

Velasquez LRS (1984) Ecologia y uso de Cedrela odorata L. en Misantla. Ciência Florestal, 9:23-36.

Williams RN, Jelínek J \& Habeck DH (1988) Annotated bibliography of the genus Conotelus (Coleoptera: Nitidulidae). Miscellaneous Publications of the Entomological Society of America, 69:01-12. 